\title{
Euro-Scepticism In Turkey of AKP Period in the Context of Temporary Tensions and Permanent Interests
}

\author{
Dr. Hulya Eski Uguz \\ Selcuk University \\ Rukiye Saygili \\ Selcuk University
}

\begin{abstract}
Turkey's relationship with the European Union (EU) has a long history that reaches back to its application for associate membership in the European Economic Community (EEC) in July 1959 and the resulting Ankara Agreement in 1963. Turkey made its official membership application in 1987 and was granted official candidate status in 1999. Throughout this long process, Turkish political elites perceived EU membership as an ideal for Turkey and highlighted their commitment to their alization of Turkish accession to the EU. However this ideal, began to change towards the second half of the 2000s. Many commentators take October 2005 the official start of membership negotiations between Turkey and the EU, as the beginning of the end, the turning point where the 'golden age' of the EU membership project ended, after which it gradually began to Euroscepticism. There are more than enough reasons for the growing Euroscepticism in Turkey. In this context, the study aims to analyze the reasons of Euroskepticism in Turkey with particular focus on Adalet ve Kalkınma Partisi-AKP (Justice and Development Party) and how this suspicion would affect the membership course.
\end{abstract}

Keywords: Euro-Skepticism, Turkey, Justice and Development Party.

\section{INTRODUCTION}

Formation of the European Union had its objective in the beginning to improve the economic development in the member states and to promote exchange of goods. At that stage, another objective of the formation was to reduce the effect of the national factor in the relations between the states. European people had learnt, in a tragic way through two world wars, which both had strong ethno-nationalist emphasis, that a share communal domain was a means for socio-economic and national egoism specific to the sovereign states. For these reasons architects of the European Union had focused on prioritizing the economic issues with the thought that an increase in the overall welfare level would enhance the level of 
tolerance (Condruz-Bacescu, 2014). This argument has been supported with a great faith by many countries. Nevertheless, the faith in the European Union has turned into a suspicion, initially, due to economic concerns, then, due to political reasons following the Maastricht Treaty. Thereby, this counter stance referred to as Euro-skepticism has become the basic policy of several political parties in member and candidate countries over time.

While initially the rhetoric of "becoming part of Europe-the civilized world" was passionately embraced by both political elites and intellectuals in Turkey and EU membership was evaluated in an idealist framework; the developments inthe course of membership have eroded the said idealism in Turkish society, and changed the relationships with EU into a more pragmatist and skeptical structure. In this context, the study aims to analyze the reasons of Euro-skepticism in Turkey with particular focus on Adalet ve Kalkınma Partisi - AKP (Justice and Development Party) and how this suspicion would affect the membership course.

\section{FROM FAITH TO SUSPICION : ORIGINS AND EVOLUTION OF THE EUROSCEPTICISM}

The concept of Euroscepticism is first seen to have been used on the newspaper The Times on 11 November 1985 to define the skeptic opposition to the European Union and its policies. Nevertheless, the concept would gain popularity worldwide with the well-known "Bruges Speech" of Margaret Thatcher, the Prime Minister of Britain, on 20 September 1988. The opposition in the speech of the Prime Minister in Brussels that sovereignty of the European Union would supersede and annihilate the sovereignty of Great Britain was going to make a considerable impression (Apodaka, 2015):

"We have not successfully rolled back the frontiers of the state in Britain, only to see them reimposed at a European level, with a European super state exercising a new dominance from Brussels".

The speech of Thatcher in 1988 made a significant impact on the discourse encompassing the EU. This impact indeed resulted from the fact that Thatcher was the first European leader to have first directly challenged the direction proceeded by the European Union. With this speech, an agenda shaped by the politicians, public and media began to form around the Treaty on European and the concept began to be discussed in media and political spheres (Usherwood \& Startin, 2011).

While historical origins of the concept are in Great Britain, the concept started to increasingly take root in other places with signing of Maastricht Treaty in the early 1990s. However, in those places, the concept of "Euroscepticism" adapted in a different way by being articulated to the national political discussions. Thus, the concept began to gain meaning with different national political conventions and different experiences of different states shaped by the discussions 
encompassing the European integration. For example, the concept of "souverainist" could be used instead of Eurosceptic. In this example, souverainism defines a policy targeting to protect national sovereignty of the state in both national and economic issues. This is a strong negative position toward the European integration when compared to those who defend less integration in certain fields of policy or who are against grant of more sovereignty to the political structures and institutions of Europe (Harmsen et al. 2004).

Spread over by being evolved with Maastricht Convention, and originated from Britain, the most common definition of Euroscepticism known is by Paul Taggart. Having defined the concept in a very inclusive manner initially, Taggart defines Euroscepticism as the expression of the thought of entire or unconditional opposition to the European Union as well as a conditional and qualified one. Later, Taggart was going to revise and narrow this broad definition with a specific reference to the Central East European countries. In this narrow and specific definition, the concept of Euroscepticism now has two different appearances: 'soft' and 'hard". Hard Euroscepticism implies rejection of the political and economic integration of Europe in its entirety and opposition to membership of one's own country or its staying as a member to the European Union, whereas soft Euroscepticism defines conditional or qualified opposition to the European Union (Taggart \& Szczerbiak, 2001).

In addition to the discrimination between hard and soft Euroscepticism, the two appearances of Euroscepticism may be discriminated as ideological and strategic considering the underlying driver. Ideologically driven Eurosceptic is under the influence of Euroscepticism due to its own ideological stance. His values and normative political targets stem from its ideologies in the beginning. Hence, a political party chooses and adopts a hard or soft Euroscepticism stance against the objectives, policies and targets of European Union. On the other hand, the skepticism we encounter in the strategically driven Euroscepticism is nothing else than a pragmatic attitude assumed by the parties usually to expand its group of voters, attract new voters or broaden its political influence zone, although the ideological stance of the party is not so different (Ultan \& Ornek, 2015).

It is possible to mention about different reasons for the syndrome, named as a British syndrome in the beginning, and spread to whole continent nowadays. Among all major criticism for EU action is the democratic deficit, lack of transparency, lack of flexibility, complicated language, the trend of creating a highly centralized super state, fear of a symbolic threat to the national communities. The major obstacle in relations with the European institutions seems to be the impossibility to identify suitable ways of managing the relationship national vs. supranational at the level of governmental responsibilities (See Table 1) (Condruz-Bacescu, 2014). It should also be noted that aforementioned 
reasons also vary in historical perspective. Until the 1990s, skepticism involved macroeconomic performances of the countries; suspicion was rising as inflation and unemployment increased, whereas falling as inflation and unemployment decreased. In the subsequent years, we confront the individual economic suspicions characterized as a reaction to the common market as the reason for suspicion. According to this explanation, the increasing job insecurity of individuals brings about anger at EU and a suspicion emerging on anger. In the 1990s, despite good economic conditions, the increase in suspicion about EU brought about shift of the attention in understanding skepticism from economic reasons to social and political reasons. This is mainly because that, following Maastricht Treaty, as the European integration advanced from establishment of a common market to formation of an administrative method, skepticism began to combine with the concern of erosion of national sovereignty and national identities. Based on these explanations, it is possible to suggest that the policies conducted by EU are determined within the framework of their relationship with national interests. A skepticism emanates from the perception that EU poses a "cultural" threat to what is national and the economic interests (Koklu, 2013).

Table 1: Types of Euroscepticism

\begin{tabular}{|c|c|c|c|}
\hline $\begin{array}{l}\text { Euroscepticism based } \\
\text { on economic criteria }\end{array}$ & $\begin{array}{l}\text { Euroscepticism } \\
\text { based on the crite- } \\
\text { ria of sovereignty }\end{array}$ & $\begin{array}{l}\text { Euroscepticism } \\
\text { based on demo- } \\
\text { cratic criteria }\end{array}$ & $\begin{array}{c}\text { Euroscepticism } \\
\text { based on political } \\
\text { criteria }\end{array}$ \\
\hline $\begin{array}{l}\text { Quantifies pragmati- } \\
\text { cally the major benefits } \\
\text { and costs originating } \\
\text { from EU membership, } \\
\text { resulted or not from a } \\
\text { cooperative process. }\end{array}$ & $\begin{array}{l}\text { Considering that, } \\
\text { at EU level, coop- } \\
\text { eration shall not be } \\
\text { a challenge to na- } \\
\text { tional sovereignty. } \\
\text { These eurosceptics } \\
\text { support suprana- } \\
\text { tional cooperation } \\
\text { in matters that the } \\
\text { state cannot manage } \\
\text { alone (such as en- } \\
\text { vironmental issues } \\
\text { and the fight against } \\
\text { organized crime), } \\
\text { but wish to preserve } \\
\text { national skills for } \\
\text { socio -cultural } \\
\text { policies. }\end{array}$ & $\begin{array}{l}\text { Perceives the cur- } \\
\text { rent institutional } \\
\text { structure of the } \\
\text { Union as insuffi- } \\
\text { cient in terms of } \\
\text { representation and } \\
\text { democratic partici- } \\
\text { pation of citizens. }\end{array}$ & $\begin{array}{l}\text { Assesses EU action } \\
\text { based on the doc- } \\
\text { trine of belonging } \\
\text { to a political family; } \\
\text { analysts believe that } \\
\text { the dominant form } \\
\text { of this disproof is } \\
\text { social }\end{array}$ \\
\hline
\end{tabular}

Source: Condruz-Bacescu, 2014.

\section{EURO-SCEPTICISM IN AKP PERIOD: OUTGROWTH DISTANCE AND SELECTIVE ADOPTION}

Turkey's relationship with the European Union (EU) has a long history that reaches back to its application for associate membership in the European Economic Community (EEC) in July 1959 and the 
resulting Ankara Agreement in 1963. EU membership has become a reality for the Turkish public and elites, and is seen as a means to further national democratisation, modernisation and economic development (Buyukbay, 2010). This faith, however, began to change towards the second half of the 2000s. Many commentators take October 2005 the official start of membership negotiations between Turkey and the EU, as the beginning of the end, the turning point where the 'golden age' of the EU membership project ended, after which it gradually began to Euroskepticism (Yaka, 2016). There are more than enough reasons for the growing Euroskepticism in Turkey. In this context, the Customs Union participated in without becoming member, the Cyprus problem hindering opening of the negotiation chapters, Copenhagen political criteria as one of the reasons increasing particularly the nationalist reactions, Turko-scepticism describing opposition of EU members states to EU membership of Turkey, and the partnership relation which did not end up with membership, as well as the membership course that has been continuing for a long time. In addition, the Sevres Syndrome describing the thought that EU demands would abolish the nation-state structure of Turkey, EU demands do not solve the terrorism problem, but rather they further strengthen it, and the religion difference emphasizing that the EU consisting of Christian countries would not make Turkey, with a great majority of Muslim citizens, can be stated to be as much important reasons at least as those in the first group (Tezcan \& Aras, 2015).

While this study aims to discuss the Euro-skepticism in Turkey with particular focus on AKP, it should be firstly noted that only AKP does not hear of a suspicion about Europe, various parties have had suspicion about EU due to the reasons listed above. However, what makes AKP different from others is the fact that it sees the course of membership to EU as a practical instrument for achieving its goal. In fact, the origin of this attitude can be found in the National Vision Movement, where AK Party has its roots. National Vision Movement is known to show an explicit opposition to the West, which constitutes the main axis of Turkish foreign policy, thus, to EU. Erbakan, the founding leader of National Vision Movement, and his parties criticized EU for economic, cultural and political reasons. According to Erbakan, EU was a Christian club with imperialist desires on Turkey. As will be discussed in the following part,National Vision Movement (Milli Gorus Hareketi) under the leadership of Erbakan modified its rigid stance towards the EU over time.Despite the Movement's Eurosceptic stance,particularly in late 1990s the party adopted a more positive discourse to the EU. In Turkey, political Islamists have been repressed for being a threat to secular character of the state and their parties have been closed for multiple times. In the 1990s, EU placed much more importance to the democratization and human rights, and the political Islamists in Turkey perceived EU as a tool to transform Turkey 
particularly in the areas of democratization, human rights, religious liberties and the influence of military on politics. Verney claims that, as of 1990s Islamists left behind their rigid Eurosceptic approach since they realized that "Europeanization, as a path to democratization, could create a framework that allows the establishment of a stable Islamist government". While the assumption of establishment of an "Islamist government" is too assertive, it is a fact that,particularly following 28 February period ${ }^{1}$, political Islamists have, as will be seen in the next part, used Europeanization to enhance human rights and democratization in Turkey for their own interests (Cicek, 2012). When the Islamist-rooted AKP came to power in November 2002, it initiated a vigorous campaign to accelerate Turkey's pace toward Europe. Given the then explicit and strong support of the Turkish society to EU membership, strengthening of Turkey's European perspective has been quite instrumental for the AKP to consolidate its place within the political establishment (Kaliber, 2013). In this context it is possible to say that AKP took over as an instrument for its own period the proEUstance of the National Vision that was dominant in their most recent period, turned it into a strategy which it put into practice or used in the area of domestic-foreign policy (Tezcan \& Aras, 2015). As expressed by Balci (2013) and Alessandri (2010), complete acceptance of the EU objective by AKP, which was in more need for international support than other political parties since 2002 to gain political legitimacy, has served the process of legitimation of the party in Turkey and international areas. In addition to being part of the said legitimization process, the encouraging expressions of EU inthe summits 2000, 2001 and 2002, also, the emphasize on establishment of civil control on the military (Yankaya, 2009) have turned harmonization with EU norms as the only peaceful means of restricting role of the military in democracy of Turkey (Dogan, 2005) into a useful instrument. In short, EU norms have been seen as an opportunity for expanding the political, economic and cultural space that had contracted for Islamic groups in the 28 February period, the democratic terms stipulated by EU prior to participation have both strengthened and legitimated the positions and demands of Islamic groups (Yankaya, 2009). Additionally to all, in

Inquipy 2016/1 early 2000s there was a huge public support for the EU membership in Turkey and it was rational for the newly-established AKP to adopt a pro-EU stance. In 2002, rate of the supporter of Turkey's membership to EU was around 64\%. Taking a pro-EU approach AKP also aimed to get support of liberal and central media, business organizations

\footnotetext{
${ }^{1} 28$ February 1997 is one of the most important dates in Turkish democratic history. At the regular meeting of National Security Council on 28 February 1997 the government in which Erbakan was the Prime Minister was given a list of proposals aiming to "prevent what the Council saw as Islamization of the country". After the National Security Council summit harsh discussions on the secularist structure of the state were made in political and public level. For some circles Erbakan and his party were accused of being against secularism. As a result of these pressures the Erbakan government resigned in June 1997. This period was called 28 February Process and post-modern military coup in Turkish democracy literature (Cicek, 2012).
} 
like TUSIAD and civil society organizations.EU membership was so popular among the public that pro-EU approach helped to the electability of the AKP. The EU objective was particularly important in order to continue the political reforms and to unite different groups around the reforms. And the AKP comprehended this atmosphere in Turkey and embraced the EU process. As the majority of public was enthusiastic about membership, it would have been irrational for the AKP to adopt a Eurosceptic approach (Cicek, 2012).

This has lasted until 2005, the AK Party in power has constantly expressed its pro-EU views on one hand, and started to quickly realize the reforms require for harmonization on the other hand. So, Onis (2008) designates the period through 2002 to 2005 as the gold age of EU process. In this period AKP combined domestic and foreign policy issues in order to use the external factors for the transformation of Turkey. In other words domestic politics in Turkey were Europeanized in this period (Cicek, 2012). Following commencement of the negotiations on 3 October 2005, very interestingly and paradoxically, the Euro-enthusiasm of the AKP cadres in the early 2000s was replaced by Euro-fatigue and postponement of the implementation of EU reform strategy by the incumbent government. The second and third terms of the AKP rule (2007 to the present time) are marked by Euro-skepticism and a drift from Europeanization (Kaliber, 2013). According to Ozcan (2010) and Yaka (2016), what ended the golden age is the fact that AK Party, which had shaped its legitimacy and its difference from the former line on the basis of establishment of close relationships with EU, is not in need of this relationship as much as it was before. The rising hegemony and public support of the AKP, which secured $47 \%$ of the votes in the 2007 elections, enabled the government to initiate a social and political transformation without needing the instrumentality of the EU membership project. While agreeing with this idea, it should also be stated here that there are other reasons which increased skepticism in Turkey in that period. For example, in December 2006, the EU suspended negotiations on several chapters of the accession negotiations, the reason for that is Turkey refused to allow (Greek) Cypriot ships and planes into Turkish facilities. Given Turkish and Turkish Cypriot support for and Greek Cypriot rejection in 2004 of the UN-sponsored Annan Plan to reunify the island, many Turks felt that this decision was unwarranted and evidence of the EU's 'unbalanced' approach to this problem. Expressions of antiTurkish sentiment from European leaders - containing Germany's Angela Merkel and France's Nicholas Sarkozy- also contributed to the problem (Kubicek, 2011). European leaders have declared openly on several occasions that Turkey would not become a full EU member at the end of the process and Turkey's accession would "deal a fatal blow to the very notion of European identity (Usul, 2014). Beside the Cyprus problem, Double Standard Treatments and French-German 
Attitudes, negative perceptions among the Muslim and Western world also played an important role in the rise of Euro-skepticism among Turks. Following the September 11 attacks by the Muslim terrorists, Islam phobia started to rise and European's view of Islam changed from bad to worse by the influence of the European media. This eventually resulted in a decrease of the support of European people for Turkey's membership to EU,which in turn reduced the enthusiasm of Justice and Development Party for EU Membership (Guler, 2011). The decree of European Court of Human Rights (ECtHR) on Leyla Sahin in 2005 was totally a breaking point. It was a monumental development that the Grand Chamber of the ECtHR agreed to hear Sahin's case at all, since two previous applications concerning Turkish headscarf had been ruled inadmissible. Nevertheless, Sahin case ended up with temporary defeat of the hijab supporters. In the hijab case, the Grand Chamber concluded that fundamental rights could be interfered in order to protect others' rights and freedoms and to maintain public order. While acknowledging that the prohibition was an interference in Sahin's right to express her religion, the Chamber decided that prohibition could be applied in order to protect rights of third parties, maintain public order, assure the principles of equality and laicism in Turkey. This decision of ECtHr was not welcome at all by the AKP leaders, who saw the Europan Union a liberating power in terms of religious freedoms as well as release of the prohibition of hijab. The AKP's disappointment immediately turned its elite and clientele Eurosceptic, revealing that the AKP had actually perceived the EU as an instrument (Kaya, 2009).

As a result of all these developments the AKP is reflected in the hardening tone of the then Prime Minister, now President, Recep Tayyip Erdogan, who frequently invites the EU to 'play it open', to be 'the man of his word', etc. Those toughening remarks were not all empty gestures. The Turkish government may feel that it has other options besides the EU. The AKP has started to pursue a new foreign policy strategy, that aims to construct Turkey as an independent and respected regional and global player. Several scholars have suggested how ideas

Inquipy 2016/1 of 'neo-Ottomanism' and the desire for greater engagement with the Muslim world have animated Turkish foreign policy under the AKP government. Part of the motivation is economic, as Turkish economic interaction with its non-EU neighbours grew markedly in the second half of the 2000s. With the Turkish economy growing by over $10 \%$ in 2010 while European economies remained stagnant, some began to question how much Turkey really needs Europe. Older strategic alliances are also being re-considered (Yaka, 2016; Kubicek, 2011). Given also the harsh effects of the Eurozone crisis, the self-confidence of Turkey in its relations with EU and its thought of seeking for other strategic partners can be understood better. Nevertheless, a cyclical change rather than a permanent change in this balance of power may be interpreted as a sign of the inferiority and superiority complexes 
shaping the psyche of the Turks in their relations with Europe. Keyman and Aydin-Duzgit (2013) (cited by: Yaka, 2016) refer to this new appearance of Euroscepticism, i.e. underestimating the importance of Europe and overestimating the power of Turkys as a global power as delusional Euroscepticism.

Despite all these suspicions and thought of the then President Erdogan involving participation in the Shanghai Cooperation Organization instead of EU so as to expressly show Brussels that it is not the only option for Turkey, as also expressed by Tezcan and Aras (2015), EU membership desire of AK Party continues in principle. This does not mean that Euro-skepticism has come to end in AKP, but implies that AKP has realized the perceptual distinction between Europeanness and EU membership, and that it has succeeded to approach the issue of EU pragmatically.

\section{CONCLUSION}

In signing convention with EEC, Turkey did had done this due the concern of not being excluded from the organizations in Europe, which it regarded as the tie to modernization, on one hand, and as a result of a pragmatic concern like security. Regarded as a foreign policy and security instrument in the beginning, EU could not receive much support from publicin this respect, but remained merely the preference of economic and political elites. However, several segments become passionately desirous about membership to EU for economical motives, while some desired for its values inherent in modernity. Besides the faith in modernity, it worth to note that Turkish people have always had the suspicion about Europe and its integration due to various reasons. In this context, it can be suggested that the concerns about Europe as reflected in discourses of AK Party cannot be attributed only to AKP, but that the public and almost all of the political parties in the arena of politics have the same concern. What makes AKP unique in this respect lies in that they have turned the course of membership to EU into a practical instrument for their own goals by realizing the perceptual distinction between Europeanness and EU membership.

\section{REFERENCES}

Alessandri, E. (2010). "Democratization and Europeanization in Turkey After the September 12 Referenum”, Insight Turkey, 12(4), 23-30.

Apodaca, A. (2015). Information Guide Euroscepticism, http://www.cardiff.ac.uk/ in srv/resources/edc/Euroscepticism.pdf

Balci, A. (2013). “Türkiyede Üç Tarz-1 AB Siyaseti: Post-Yapısalcı Bir Okuma”, Uluslararası Hukuk ve Politika, 9(35), 1-19.

Buyukbay, C. (2015). "Euroscepticism in Turkey Power and Beyond”, http://www. peterlang.com/download/extract/89249/extract_266685.pdf

Condruz-Bacescu, M. (2014). "Euroscepticism Across Europe: Drivers and Chal lenges", European Journal of Interdisciplinary Studies, 6(2), 52-59.

Cicek,C.(2012)."Justice and Development Party and the EU: An Inquiry on the De bates of Euroscepticism in Turkey",(Basılmamış Yüksek Lisans Tezi), 
Middle East Technical University, Ankara.

Dogan, E. (2005). “The Historical and Discoursive Roots of the Justice and Develop ment Party's EU Stance", Turkish Studies, 6(3), 421-437.

Guler, E. (2011). "Eurospectism in Turkey on the Way to the EU", https://www.aca demia. edu/1574271/Euroscepticism_in_Turkey_on_the_way_to_the_EU

Gulmez, B. S. (2008). "A Comparative Analysis on Turko-scepticism in the EU vs. Euro-scepticism in Turkey", PSA Post Graduate Conference 2008, University of Edinburgh, the UK, www.pol.ed.ac.uk/_data/.../gulmez.doc

Gulmez, B. S. (2013). Understanding The Eurospecticism in Turkish Politics, https:// pure. Royalholloway.ac.uk/portal/files/22866477/Baris_Gulmez_phd_2014.pdf

Gulmez, B. S. (2015). "Avrupa Şüpheciliğii", Avrupa ve Avrupa Birliği içinde, Ed. C. Dinç, Savaş Yayınevi, Ankara.

Harmsen, Robert \&Spiering, M. (2004). 'Introduction: Euroscepticism and the Evolu tion of European Political Debate,' in R. Harmsen \& M. Spiering (eds.) Euro scepticism: Party politics, national identity and European integration, Amster dam: Rodopi.

Hooghe, L. \& Marks, G. (2007). Sources of Euroscepticism, ActaPolitica, 42, 119-127.

Kaliber, A. (2013). "Contextual and Contested, Reassessing Europeanization: The Case of Turkey", Paper presented at the 7th ECPR General Conference Sciences Po, Bordeaux.

Kaya, A. (2009). Turkey-EU Relations: The Impact of Islam on Europe, in Jorgen S. Nielsen et al. (eds), Yearbook of Muslims in Europe Vol.1, Leiden, Brill, 377-402.

Koklu, P. (2013). "Ekonomik Krizle Artan Avrupa Şüpheciliği”,

Kubicek, P. (2011). "Political conditionality and European Union>s cultivation of democracy in Turkey”, Democratization, 18:4, 910-931

Onis, Z. (2008). “Turkey-EU Relations: Beyond the Current Stalemate”, Insight Turkey, 10(4), 35-50.

Ozcan M. vd. (2010). Bundan Sonrası? Senaryo Analizleriyle Türkiye-AB İlişkileri, 2. Baskı, USAK Yayınları, Ankara.

Samur, H. (2015). “Polonya: İdealist Avrupalılıktan Pragmatist Avrupa Birliği Üyeliğine”, Uluslararası Hukuk ve Politika, 11(41), 37-68.

Taggart, P. \& Szczerbiak, A. (2001). 'Parties, Positions and Europe: Euroscepticism in the Candidate States of Central and Eastern Europe', paper presented at the Annual Meeting of the Political Studies Association, 10-12 April, Manchester

Tezcan, E. \& Aras, İ. (2015). “Adalet ve Kalkınma Partisi'nde Euroseptisizm: Avrupa Birliği Desteğinin Eleştiriye Dönüşümü”, Uluslararası Hukuk ve Politika, 11(41), 1-35.

Ultan, M. O. \& Ornek, S. (2015). "Euroscepticism in The European Union”, Interna tional Journal of Social Sciences, 4(2), 49-57.

Usherwood, S. \&Startin, N. (2011). "Euroscepticism as a Persistent Phenomenon" At the University Association of Contemporary European Studies 41st Annual Conference (Exchanging Ideas on Europe) at Robinson's College, Cambridge, September avilable at http://uaces.org/documents/pa pers/1101/usherwood.pdf

Usul, A. R. (2014). "Is There Any Hope on the Revival of EU-Turkey Relations in the "New Era?", Turkish Studies, 15(2), 283-302

Yaka, O. (2016). "Why Not EU? Dynamics of the Changing Turkish Attitudes Towards EU Membership", Journal of Contemporary European Studies, 24(1), 149-170,

Yankaya, D. (2009). “The Europeanization of MÜSİAD: Political opportunism, Eco nomic Europeanization, Islamic Euroscepticism”, EU-Turkey: Sociological Approaches, (9), 1-18. 


\title{
A Look at Modern Social Religion as a Regressive Concept: Exploring the Power of Misinformation
}

\author{
Denis Kucukovic \\ Western Sydney University
}

\begin{abstract}
The concept of religion is constantly under the scruples of redefinition. Ranging from arguments regarding the similarity and validity of state and theistic religion, to the morality of those who choose to reject the latter, religion is by far the most heated topic of discussion in any social circle today. Due to this, one would be remiss to pass up the opportunity to document the newly sprung notion of social religion; in particular, the morphing of social activism into social religion. The fact that contemporary theistic belief is increasingly held in a communal sense reveals that its purpose can be effectively categorised as social; hence the marrying of theistic and societal religion in this work. Though the distinctions are clear and numerous, the similarities cannot be ignored. Rationality needs more practice.
\end{abstract}

Keywords: Religion, Misinformation.

\section{INTRODUCTION}

The concept of religion is constantly under the scruples of redefinition. Ranging from arguments regarding the similarity and validity of state and theistic religion, to the morality of those who choose to reject the latter, religion is by far the most heated topic of discussion in any social circle today. Due to this, one would be remiss to pass up the opportunity to document the newly sprung notion of social religion; in particular, the morphing of social activism into social religion. Third wave Feminism (not to be confused with the successful and absolutely justified first wave) and its adherents (often dubbed regressives/Social Justice Warriors or simply 'SJW') have become fuel for the toxic mindset that is modern social religion. It is important to note the true definition of religion. Though religion does not mean faith, when one uses the word it has historically most likely been used in the theistic sense, its true meaning covers all forms of obsessive and zealous adherence to a set of established rules. This distinction is the root of religion's inherent negativity. One must place 'faith' in an ideology in order to become a zealot. This faith is not subject to internal rational scrutiny (if it is to be maintained) and thus is inherently irrational, regressive, and rather imagined. 


\subsection{Problem Statement}

The idea of an imaginary ideology is not difficult to understand, or so one would hope. All one has to do is conduct a thought experiment. First, take your moral values, if they are religiously driven then you already inadvertently understand rationale based on warped reality, and then assign them to an arbitrary system of objectively false beliefs. It can be anything. It can be a belief in a God, a strict code of law set by an illiterate man who lived thousands of years ago, or even a social movement based on outdated facts. Now, your belief may only go this far, which is not physically dangerous but surely mentally so, but others may take your ludicrous notions and carry them into the civilised world as their gospel. If the question of danger is taken care of and proven to be insignificant, as it always should be, then one must turn to truth. Why must a person believe in fiction in order to justify reality? The answer is fear. The idea of ignorance through fear is an idea that has most recently, in mainstream thought, been championed by neuroscientist and moral philosopher Sam Harris (2004). To understand religion, he claims, one need only look to the emotions evoked when a vulnerable mind contemplates death. That is the key to all religious belief. Harris clearly outlines the trickle-down effect of fundamentalist religious belief. If religion is wrong about the origins, behaviour, and future of the universe, it is then more than reasonable to suggest that its idea of life after death is equally false. This is where fundamentalism begins. Fear of death. Fear of reality. To counter this fear, one must conjure up, or simply adopt, a false ideology in the hopes that it will ease this fear. To consolidate this belief, one must then spread this view with intense fervour, to neighbours, friends, and even children, so that they may feel validated in their ignorance. This is the principal of 'imaginary ideologies.' It is so rampant, even today, that it has poisoned the minds of those who would otherwise behave in a manner appropriate to $21^{\text {st }}$ Century rational thinking. The tactic to spread one's warped logic extends beyond traditionally lax familial ties. Unlike contemporary theistic religion (which is not to insinuate its innocence, but rather its relativity), modern feminism believes in unified, unchallenged policing of thoughts. To stray from the established 'sexist-free' mindset is not to have a lapse in judgement, it is equivalent to true crime. The punishment is social and economic exile.

\section{THE REGRESSIVE LEFT}

Perhaps the biggest perpetuator of this wilful ignorance is the 'regressive left.' A term popularised by author Maajid Nawaz, it refers to the fundamental apologist section of the traditional liberal leftwing. In the interest of all encompassing, misguided multiculturalism, the regressive left have deemed it an act of bigotry to criticise certain ideological belief systems; in particular, Islam. $\operatorname{Nawaz}(2013$, p. 210) focuses on the word 'regressive' as this distortion of liberalism allies 
itself with the most regressive theocratic regimes of the middle-east. By sheltering outdated ideas from criticism, regressive ideals have begun to spin a tale that paints other left-wing subscribers as having a narrow and exclusive mindset; a most ironic and misinterpreted set of beliefs. This sheltering includes more irony than sense. Those who adhere to the strict and yet confounding rules of regressivism seek to eradicate what they deem as racism. This is done in an attempt to eliminate the stigma that certain races might carry, warranted or not. What needs to be understood however is that if one chooses to lump people together based on the colour of their skin (as regressives are wont to do), then one must accept the facts and statistics that arise from such a blanketed categorisation.

\subsection{Liberal or Regressive?}

The idea behind such a regressive ideology is a misapplication of classic liberal principles. By misinterpreting the liberal principle of acceptance, the regressive left become beacons for respect without criticism (Nawaz, 2013 p. 210). This idea is so ingrained in their community that any form of religious criticism, contemporarily this is again most common with Islam (as they ignore their own), is seen as bigotry or even racism; quite a stretch of the definition considering that religion is not a race. The true concept of liberalism subscribes to the idea of acknowledgement. It operates on the belief that all ideas must be acknowledged if constructive discussions on morality and real world application are to occur. This does not however imply that any such idea must be respected or become immune to ridicule. All ideas must be tested intensely. Without this approach, societies run the risk of allowing ignorance and bigotry to run rampant without an intelligent challenge to the principles that foster them. This is exactly what has occurred in the western world, and through association, the middle-east as well, with the rise of this 'regressive left.'

\section{THE 'SOCIAL JUSTICE WARRIOR'}

Without a filter on ridiculous beliefs, this idea is most dangerous in the realm of politics. Beginning largely as a criticism on the treatment of Islam by the west, the regressive left is effectively the result of a knee-jerk reaction to neo-conservative foreign policy implementation (Nawaz, 2013). This idea is further based on the belief that organised military invasions of middle-eastern nations are worse than smaller, sporadic acts of Islamist terrorism. While it is obvious that these ideals carry the risk of infecting the political sphere, the real danger of this ideology lies in its sense of duty. Those that subscribe to it have been driven by a misguided sense of social justice to intensely challenge what they deem as bigoted criticisms of middle-eastern cultural and religious values. The intense fervour with which this distorted world view is being pushed is analogous to an attempt at ideological warfare. Believing victory to be more important than intellectual conversation, 
the regressive left have made it their goal to attack those who do not share their views. The regressive idea is not to look at the ideas being criticised, but merely focus on the fact that they are being criticised. To the regressive left, belief systems should be immune to criticism as anything else would mean denying multiculturalism (unless it regards their own agenda, such as the systematic destruction of cis-gender pronouns). In the online world, meaning those in forums and threads dealing with social and political expectations, the subscribers have been dubbed 'social justice warriors' (SJW), rather ironically.

\section{With Us or Against Us}

Ironically, by attempting to put an end to violent clashes of ideologies, that is, the mentality of 'us against them', the regressive left have only served to strengthen that very ideal. Due to their vicious and defensive nature, the regressive left have created a barrier between dialogue and change. The only change they profess is the end to a specific intolerance which they neither genuinely interpret, nor understand. To understand the idea of criticism against Islamist ideology, one need only have the capacity to evaluate ideas for what they are truly worth. Does this ideology spread hate, distrust, or bigotry? If so, it must be open to scrutiny. It is rather interesting and bewildering to note that these regressive principles never apply to ideologies which do not hold at their core the belief in a religious truth. Following this regressive mode of thinking, an ideology must be allowed to flourish if it is held by a vast number of people. This perpetuates the idea of quantity over quality. No other argument needs to be made to reveal the ridiculousness of this ideological double standard. A rejection of this idea then leaves several topics unanswered.

\section{MORALITY}

When one rejects religion, they are left with the question of morality. The highest form of morality then becomes altruism. But why then must altruism be followed? This brings to the fore ideas of what can be called micro and macro morality. Macro morality refers to topics that deal in progress and prosperity; such as murder, rape, torture etc. Micro morality refers to manners, respect, minor human interaction etc. While all sane individuals agree on the principles of macro morality, there is a big divide in the conduct of micro morality. Since religion preys on the idea that one cannot possess macro morality without a belief in God, and for all intents and purposes this idea is a scientific fallacy, it becomes the burden of the atheist to provide themselves with specific micro moral guidelines. This is usually taken on by communities within different nations, and these ideas differ, with just cause (Hitchens, 2007).

\subsection{First Step}

Once morality is established as the greatest divide in human history, one must then develop a system of dialogue that can take place without 
violence. Though this is difficult to do, and some rightly argue that it is impossible in an absolute manner, it must be undertaken. In order to pose the question of macro and micro morality to different nations, one must understand that vast numbers of people within those nations will refuse to question their beliefs. It is then reasonable to discard those individuals. It is of no use to any form of critical discussion to have unwilling radical deniers. It cannot be argued that morality does not stem from human understanding, specifically through the passage of time (Dawkins, 2006). Context is the defining measure of morality. If one presents the idea that morality has supernatural origins, as all theistic religions claim, then that discussion is no longer useful. When one believes in an absolute power, they believe in it absolutely (this holds true for social religion too). And it is known in human nature that absolute power corrupts absolutely. Only by taking that out of the question can dialogue begin. So when one begins to talk about global morality, one must discard religious intrusion. That is the first step.

\subsection{Uphill Struggle: Reformation}

In order for effective change to take place, in the form of religious reformation, one must be prepared for a struggling 'bottom up' approach. This refers to action through dialogue and suggests its starting point as questioning the religion, not the religious; one will inevitably expose the other. This of course has many obstacles, the strongest of which is irrationality, not to mention a requirement of abnormal amounts of patience. Can this be achieved? While that remains in doubt, one must try. The most difficult aspect of the 'bottom up' approach to this suggested reformation is dialogue. Most often debaters, on both sides, are subject to intense monologues; unhelpful displays of ignorance or intelligence. To be clear, this is unhelpful in creating significant political change as those who are indoctrinated do not take kindly to intellectual criticism, regardless of its legitimacy.

\subsection{Moderate Responsibility}

The tough question remains; who is responsible for bringing about change? The answer is simple in theory: everyone. In practice however, things are quite complicated. Indoctrination, fear, and irrationality all stand in the way of reason. Religion has through history caused a mass suppression of educated rationality. This can only be remedied through grueling, relentless dialogue (Nawaz, 2013). This burden should mostly fall on religious moderates, not unbelievers. By this it is meant that because those in a position of religious influence have a certain power over other theists, it is their responsibility to make sure that their respective religion is reformed to fit the modern times that they live in. It is obvious that those who do not listen to reason, cannot be reasoned with. That is why imaginary beliefs must be tweaked to fit into modern society. It is literally a matter of trickery, not reason, when attempting to reform the ancient self-proclaimed and utterly misguided religious ideologies of both past and present. While written reform would 
be most helpful, it is impossible as that in itself would cause violent reactions. As such, the only remaining option is interpretation. That is what is meant by trickery. Together, moderates and unbelievers may in fact have a chance at global religious reformation. The question is how long will it take? No one can possibly know the answer.

\subsection{Effective Criticism}

Though without the possibility of a working time frame, one can still seek to engage in religious reformative dialogue with patience and the ability to look through a contextual lens. To do this, it is paramount to a clear understanding of religious dogma that one comprehend the complexities of free will. Riding on the coat tails of Sam Harris' work on 'Free Will', (2012) it can be understood that the views that one possesses, and the actions that these ideologies create, cannot be used to paint religious people in a black and white morality brush. While accountability is still a concept that needs refining, it is clear that indoctrination is a clear problem in realising the realities of the universe. The most difficult aspect of this case is the knowledge it brings to those who suffer from a lack of 'free will.' It has to be understood that it is not favourable to admit to such a reality. The pressure and ridicule that one may encounter when revealed to be a religious believer is often times a deterrent to enlightenment. Nobody wants to believe that they were tricked, or that they were wilfully dismissive of the truth. This is not to say that one should be wary not to offend the minds of the religious, it simply implies that one must take care to exclude them from enlightenment through shame (Dawkins, 2006). Those who have been fooled into believing a certain dangerous fairy tale should be given the chance to change their minds without feeling shunned by a community that had support doing the same. To be clear, dangerous religious ideals should be ridiculed and destroyed, but once those ideas are shattered, there should be no shame in admitting previous wrong doing through dogmatic influence. Though this seems to be a very shaky premise for acceptance, it is one that must work in order to completely integrate indoctrinated persons into modern scientific thinking.

\section{ISLAMOPHOBIA}

Without succumbing to criticisms of utilising the 'straw man' approach, it is quite easy to point out the hypocrisy of regressive propaganda regarding false Islamophobia. The most popular approach in the contemporary social media sphere is anti-white/west arguments. Those in the regressive camp claim that because the West was responsible for the Crusades, and Christian violence in general (a rather large generalisation that people fail to realise stemmed from Europe and not the United States), they are somehow now unable to criticise modern religious extremism (Nawaz, 2013). To point out the ridiculousness of this claim, one need only look to a possible future; it would mean that the Muslim population, or Middle East in general, 
would have no right to criticise any acts of fanatic violence because the culture they are a part of had at one point committed atrocities in the name of religion. Another example would be if the black population of the US began to capture and hold white slaves. Under the logic of the regressives, the white population would have no right to criticise these acts. Now, some would claim that this example is different because it is not religiously motivated, but that rebuttal in itself would suggest that religion be allowed special consideration. No organised community has the right to undermine another for no valid reason. There is no exception.

\subsection{Religion $\neq$ Science}

While it remains a heavy topic for debate, it should be quite clear that science and religion are incompatible. One at its very essence must rebuke the other to be true. Historically, the former has consistently and successfully done so to the latter. Most controversially, in recent times, the area in which religion has failed is evolution. Charles Darwin's theory of evolution is undoubtedly the most important biological scientific discovery in the history of science (Dawkins, 2006). Though unimaginable to some during his time, his hypothesis has since been proven. While the scientific community is delighted to have such a great understanding of the history of life, many religious institutions do not share this enthusiasm. To them, if evolution is true, major parts of all holy books must be false; specifically, the story of Adam and Eve. This would mean that these ancient texts have a fundamental lack of understanding when it comes to the history of humanity and the animal kingdom in general. Admitting that a holy book is false in any aspect is not something that religious people take lightly. This explains the warped logic behind the extreme backlash to the proven theory of evolution.

\subsection{Reason Over Faith}

All the attempts in this paper to advocate reason and evidence as the main proponents of human progression are not for the purpose of offense or any political agenda. While it is obvious that it is riddled with loaded statements, the hope is that this work will convince fence sitters to simply question their ideological background. It is a deluded thought to hope for religious destruction, that much is clear. It will not happen. Rather, it is important to realise that nothing should be free from question. Hopefully it will become clearer to some through a reading of this text that there is absolutely no logical reason why religion, any religion, should be subject to special treatment and able to police the thoughts of their followers. That is all that you may be. If you are religious, you are a follower. Your faith is nothing but blind. In literal terms, there is no evidence to suggest that something which has no basis in reality, exists. Sure, it can be true that specifically for theistic religions a God might exist, but is important to note the difference between maybe and definitely. There is one thing any rational mind 
must accept; one cannot possibly know if there is a God or not, but one thing that is definitely clear is that there has been no event or shred of evidence in history to suggest that believing in one is rational, logical, or factual. This same wilful irrationality is prevalent in the predominating false idea of a first world western gender pay gap. To claim that one exists is to wilfully mislead the public through a misinterpretation of the given statistics (Farrell, 2005). A belief in something that cannot be proven is lunacy. It is the wilful rejection of reason. As Lee Harris states, it is the "suicide of reason."

\section{PECKING ORDER}

Not only is religion the 'suicide of reason', it is the birth of unreason. Allowing one's life to be completely dictated by millennia old unimaginative and immoral fantasies is tantamount to mental illness. That is not said out of spite, but out of precedent. How many people have you known of (or had the displeasure of knowing) that claimed to be some form of deity reincarnate? How many of these people have you taken seriously? Your answer should be the same for any form of indoctrinating dogma as it is for the aforementioned situations. If not, you live in a mental reality perpetuated by fantastical bias. And not just any bias. Bias that is divisive, racist, sexist, and overall dictatorial. Each religion operates on a hierarchy of moral hubris (though the social kind stops at 'True Believer');

Apostate $<$ Unbeliever $<$ Uninformed $<$ Believer $<$ True Believer $<$ Priest (or equivalent) $<$ Religious Leader $<$ Prophet $<$ God

This is the hypocritical, ludicrous, and absolute judgemental system of importance in every mainstream monotheistic religion. Though each category is simply <another, they are by no means indicators of how far apart they truly are. All levels below 'True Believer' are negligible (and often times sentenced to death) in different belief systems. Mathematically, they cannot all be right. This means that if, for arguments sake (and only for arguments sake), one of the mainstream religions is true, a vast majority of the population are immediately sentenced to hell for the simple act of being born in the wrong place and wrong time, with no evidence given to persuade them to convert to

Inquiry the 'right' religion. Now take this information and apply the truth: none 2016/1 are correct. That still leaves all religions the freedom to actually believe that every opposing and equally abhorrent faith system has doomed its followers to hell through blasphemy. What rational being would believe this? There is no rationality here.

\section{Rational Approach}

What is rationality? In layman's terms it refers to something that is logical or in accordance with reason. Religion in reality is none of these things. There is nothing rational about religious dogma. An explanation full of examples need not to be given in this paragraph to reveal the irrationality behind religion. A study of any history of any 
time of any peoples will do that adequately. It is clearly a system created by humans in order to control other less educated humans. It is a top down system that can only be solved through a bottom up approach. And it is interesting to note that the term 'solved' here is not used to describe a world without religion, but rather a world rife with reason (a world without religion would be a world without the susceptibility to faith based lunacy) as no other state of being is practical or possible.

\section{REFORM}

An area that is quite contested even amongst the most ardent atheists is reformism. This is due to the fact that it largely deals with cultural identification and morality, not strictly religion. The drift is created when one side (for arguments sake we shall assume there are two strictly opposing sides) claims that reformist religions should be given the spotlight over traditional religions. That is to say, a 'secular liberal Muslim' should be given just as much, if not more, media coverage over a traditional Muslim. This is where a problem can arise. It is misrepresentation of the faith, regardless of its intention. To claim that a 'secular liberal Muslim' falls under the category of Muslim dilutes the intellectual debate of both morality and literal truth (Ali, 2015). Under this theory, if one (rightly) claims that every Muslim believes the Quran to be the true word of God through his last prophet, some (being the reformists) would claim that this is stereotyping. These statements come from an analysis of traditional Islam, not a dilution of its morally corrupt teachings. It is a mistake that is very often wrongly criticised as being bigoted and racist; the latter being semantically untrue as religion is not a race (Ali, 2015).

\section{God's Will}

Criticisms of religion can be tied to two main threads; action (physical) and truth (mental). To firmly place yourself within these parameters of critique your belief must first have a negative effect on another human being. While it is argued that even a non-believer may do this, it is certainly not by God's will that they do so. Secondly, and most importantly, your belief must be false. It is already obvious that all religious doctrines carry false ideas in both the philosophical and scientific sense. It is simple to have an unbiased view on religious teachings, regardless of belief. Simply remove 'God's will' from any action or thought that you might have (it is not hard to imagine) and then analyse your actions accordingly. You would be mortified in even your simplest religiously supernatural belief or claim. If you cannot do that, then you are indoctrinated (Hitchens \& Wilson, 2008). It is that simple. If this task is too offensive, you can do one of two things; grow up, or attempt to prove God's theistic existence. That is to say that he exists in an influential sense, guiding you and everyone (or at least attempts to do so with his supposed omnipotence) to either bliss or misery. You will not find such evidence. Then ask yourself, are you willing to believe anything if it suits your desires? 


\section{QUESTION OF FAITH}

For those who belong to a certain religious group, how is it that you choose your beliefs? Do you believe in your holy book in its entirety? If you do, you are a literal member of that sect and any other interpretation is a diluted form of worship. This is not an opinion, it is a literal fact. If you are a diluted believer, what prompts your moral decisions? How is it that you may, with a clear conscience, analyse the validity of God's will in a holy book that proclaims to be so without inconsistency? Perhaps a new perspective will help. A rather vehement religious zealot, being a true believer in the respective holy text, is entirely driven by what they perceive as the word of God. Every waking moment is thus controlled and accounted for by their theistic deity. There is no room for doubt. There is no room for rationality. This is the highest form of indoctrination and brings one to feelings of sympathy. A moderate however, is an interesting case. One who possesses the ability to filter out certain passages in a holy text but submit to others is not in a position to lecture on morality. This is where problems arise with religious acceptance in contemporary society. The regressive left wing is increasingly accepting and enabling religious moderates as though they were the pinnacle of moral affection (Harris \& Nawaz, 2015). It cannot be reasonable to suppose that one who, with the ability to rationalise decisions individually, chooses to remain either racist, homophobic, or sexist. This 'ability' often leads to a superiority complex. What these moderates see as a reformed religion is in fact a clearly conscious form of immorality. An indoctrinated religious zealot is amoral in the sense that it inhibits free will. A moderate is thus immoral with an application of this same logic.

\subsection{A Different Perspective}

Ardent religious defenders are quite akin to contemporary caricatures of 'fandom.' Their relentless and often overzealous defence of the observable plot holes in their beloved source material blinds them from the obvious truth; they aggressively follow and obsess over a work of fiction. How is this moral in any sense? It actually draws sympathy. Unlike the aforementioned 'fandom,' religious adherents carry the burden (which they enthusiastically dismiss) of proving their

Inquiry 2016/1 work of fiction to be anything but. Since the documented manmade creation of religion thousands of years ago, this has never occurred. One must then ask why? The answer is quite evident. Extraordinary claims require extraordinary evidence. In the minds of the religious however, this logic is warped; supernatural claims require supernatural evidence. Thus, their ideas cannot be falsified. While immoral, it is not unbelievable that one would attempt to keep increasingly false claims unfalsifiable when that claim is in the business of controlling all who have religious faith. Religious authority has proven to be absolute over those who are unwilling or incapable of refusing it. As is constantly proven throughout history, absolute power corrupts absolutely. Religion is embarrassingly corrupt (Hitchens, 2007). 


\subsection{Insult to Intelligence}

While it is well known that the religious are adamant about keeping their holy figures free from criticism (or even humour), it is the hypocritical nature of this that is most interesting. Attempting to filter 'offensive' critique, religion has served as a shielded weapon against reason. Planting themselves firmly in every government the world has known (Hamburger, 2002), it has become immune to constructive criticism in that it claims harassment, racism, or bigotry if this occurs. One would not be remiss in realising the glaring irony in this. While claiming to be the children of God (or champions of social justice), being the chosen few who are shown the truth, they simultaneously dismiss the validity of any opposing form of moral teaching. This is perhaps the highest form of offence to reason. Claiming exclusive divine mental intervention, all theistic religious advocates incessantly claim that God invented morality, whether one chooses to believe so (without proof) or not. What could be more offensive to one's intelligence? It is literally saying that no person that has ever lived, or ever will live, can possibly contain the mental fortitude to make their own decisions based on internal interpretations of communal morality.

\section{DIFFERENT YET SIMILAR: CONCLUSION}

The major difference between theistic and social religion is its use of manipulation. The former confuses fact into myth while the latter warps myth into fact; to accurately label them, one is deluded while the other is regressive. In both cases, it is a wilful suspension of reality. Not only do both examples constitute an obsession with the disproven, but also a complete lack of contextual comprehension. Religion is incessantly a product of its time. Taken out of that time, it has proven throughout history that it cannot survive the rationale of basic intellectual scrutiny. The modus operandi is the same; the ends justify the means.

The delusion is not simply a matter of individual consequence. One who believes in the biologically inconsistent idea that physical gender (or sex) is a social construct operates under the misguided thought that self-identification is enough to constitute reality. These matters not only affect the mentality of others who might be susceptible to such an idea, it exposes them to potential physical repercussions. Not only has it become a social vendetta to target anyone who might criticise such a drastic notion, it has warped into a politically charged subject in its own right. One who supports this case is undoubtedly in a more desirable position than one who does not. This is common to all religious adherents. To be clear, the contextual concerning factor here is potentially unwarranted prejudice. The power of misinformation needs only minute study to be revealed. The fact that contemporary theistic belief is increasingly held in a communal sense reveals that its purpose can be effectively categorised as social; hence the marrying 
of theistic and societal religion in this work. Though the distinctions are clear and numerous, the similarities cannot be ignored. Rationality needs more practice.

\section{REFERENCES}

Ali, A. (2015), Heretic: Why Islam Needs A Reformation Now, Harper.

Colman, A. (2003). Oxford Dictionary of Psychology, Oxford University Press. Dawkins, R. (2006). The God Delusion, Bantam Books.

Dawkins, R. (2006). The Selfish Gene (30th Anniversary Ed.), Oxford University Press. Farrell, W. (2005). Why Men Earn More- And What Women Can Do About It, AMACOM Hamburger, P. (2002). Separation of Church and State, Harvard University Press. Harris, S. \& Nawaz, M. (2015), Islam and The Future of Tolerance, Harvard University Press.

Harris, S. (2004). End of Faith, W. W. Norton \& Company.

Harris, S. (2012). Free Will, Simon \& Schuster.

Hitchens, C. \& Wilson, W. (2008) Is Christianity Good For The World? - A Debate, Canon Press.

Hitchens, C. (2007). God is Not Great: How Religion Poisons Everything, Hachette Book Group.

Hobsbawm, E. (2007). Globalisation, Democracy, and Terrorism, Little Brown. Joseph, E. (2004). Language and Identity: National, Ethnic, Religious, Palgrave MacMillan.

Nawaz, M. (2013). Radical: My Journey From Islamist Extremism to a Demo cratic Awakening, W. H. Allen Press. 